
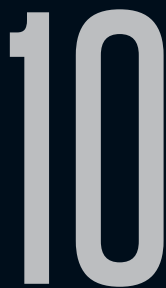

\title{
APOCALIPSE HEMATÓFAGO: AGÊNCIAS DO CORPO VAMPIRESCO NAS PANDEMIAS DE NOTURNO E APOCALIPSE V
}

Thiago Sardenberg

Recebido em 05 dez 2020. Thiago Sardenberg é doutor.

Aprovado em 10 fev 2021. http://lattes.cnpq.br/0433946339623302

https://orcid.org/0000-0002-6193-2683

thisardenberg@gmail.com

Resumo: Em meio a grande diversidade de universos literários construídos a partir da figura mítica do vampiro, sempre figurou de maneira expressiva a questão da contaminação. Um devir vampiro é comumente subordinado ao contato direto com a entidade ou, minimamente, com seus fluidos corporais; outrossim, não obstante a natureza atribuída ao vampiro - seja a de um ser sobrenatural ou mesmo a de um corpo infectado por agente inteiramente natural - o tema do contágio, ou o próprio medo dele, se reafirma através dos séculos como recorrente nessas narrativas. Neste ensaio, consideraremos duas narrativas vampirescas do século XXI, Noturno (2009) de Guillermo del Toro e Chuck Hogan, e a série televisiva Apocalipse V (2019) da Netflix, nas quais o corpo do vampiro não apenas figura como, ou carrega, um vetor epidemiológico, tornando-se responsável pelo que se desenvolveria como uma pandemia devastadora, como também reflete e responde aos anseios de seus contextos de 
produção - como a figura do terrorista estrangeiro, o bioterrorismo, e a própria ansiedade causada por nossa fragilidade diante do advento de uma pandemia em larga escala.

Palavras-chave: Vampiros na literatura. Distopias. Narrativas apocalípticas. Pandemias. Noturno. Apocalipse V.

Abstract: Amongst the multiplicity of literary universes centered around the mythical figure of the vampire, the issue of contamination has always figured in a prominent way. Becoming a vampire is usually subordinate to the direct contact with the entity or, at the very least, with its bodily fluids; also, regardless of the nature attributed to the vampire - whether that of a supernatural being or that of an entirely natural infected body - the theme of contagion, or the very fear of contagion, is reasserted through the centuries as recurrent in these narratives. In this essay, we will consider two vampire narratives of the twenty-first century, The Strain (2009), by Guillermo del Toro and Chuck Hogan, and the Netflix TV series V Wars (2019), in which the vampire body not just figures as, or carries, an epidemiologic vector, becoming responsible for what would develop as devastating pandemics, but also reflects upon and answers to the fears that are intrinsic to its contexts of production - such as the figure of the foreign terrorist, bioterrorism and the very anxiety derived from our fragility in face of the advent of large scale pandemics.

Keywords: Vampire literature. Dystopias. Apocalyptic narratives. Pandemics. The Strain. $V$ Wars.

Em meio aos múltiplos e não raramente conflitantes universos literários construídos a partir da figura mítica do vampiro, sempre figurou de maneira expressiva a questão da contaminação. O devir vampiro costuma ser, nessas narrativas, 
subordinado ao contato direto com a entidade ou, minimamente, com seus fluidos corporais; outrossim, não obstante a natureza atribuída ao vampiro - seja a de um cadáver que retorna, a de um corpo possuído por força ou entidade sobrenatural, ou ainda meramente um corpo infectado por um agente natural - o tema do contágio, ou o próprio medo dele, se reafirma através dos séculos como nelas recorrente. Esse contágio, entretanto, nem sempre opera estritamente em função de uma fisicalidade corpórea; frequentemente, tratamos também de contaminações que ameaçam, de forma mais ampla, as estruturas de poder e os próprios princípios sociais e morais que regulam as delimitações físicas de determinado espaço.

Em Drácula (1897), narrativa seminal de Bram Stoker, nota-se como o autor constrói sua Londres de fin de siècle como um reino de austeridade no qual o civilizado, a temência a Deus e o tecnológico convivem aparentemente de maneira harmoniosa, enquanto a região romena da Transilvânia é adornada por superstições locais e pelo plano do sobrenatural, um espaço no qual o vampiro medievo podia prosperar. A tensão na narrativa se exponencia na medida em que o vampiro se desloca geograficamente, não apenas ameaçando a integridade dos corpos vitorianos como também seus códigos morais: era a ameaça da profanação das convenções de familiaridade doméstica pelo bárbaro estrangeiro.

Um eventual contato com o vampiro naquela narrativa, frequentemente retratado com traços marcantes de sexualidade e sórdida abjeção, faz Mina Harker gritar para si mesma, horrorizada, após recobrar seu senso: "Impura! Impura!" (STOKER, 2014, p. 219), algo que nos remete diretamente à Bíblia quando, 
em Números, Deus aponta que "aquele que tocar o cadáver de algum homem, será impuro por sete dias" (19:11) e também, de forma ainda mais transparente, quando em Levítico é mencionado que a pessoa portadora de doença contagiosa de pele deveria gritar "Impuro! Impuro!" (13:45) e que "por todos os dias em que a praga estiver nele, será impuro" (13:46).

Stoker articulava assim uma analogia do vampirismo como doença - e do vampiro em si como seu vetor. Tal doença era simultaneamente do corpo e da alma, se espalhava como uma infecção pelo corpo social, tornando "impuros" aqueles por ela tocados, e deixando em seus pescoços suas chagas características, marcas de um corpo penetrado/profanado. Tal como um vírus, o vampiro invadia o corpo estrangeiro, usando-o como meio para sua replicação, afinal, "sua habilidade de reprodução é localizada oralmente, não genitalmente; através do sangue o vampiro se alimenta, se gratifica e se reproduz" (TOMC, 1997, p. 99, tradução livre). Naquela narrativa, podemos observar como uma existência como essa, regida pela constante gratificação, era tanto temida quanto odiada, especialmente em relação às mulheres, que desse "mal" deveriam ser protegidas a todo custo.

No que nos deslocamos no tempo, a figura do vampiro viria a se posicionar como catalisadora de ansiedades outras, transfigurando-se em relação às especificidades sociais a si contemporâneas, já que "cada vez que a tumba é aberta e o adormecido inquieto ressurge, a mensagem proclamada é transformada pelo ar que dá vida ao orador" (COHEN, 1996, p. 5, tradução livre). Sendo um construto cultural, o corpo do vampiro, enquanto monstro ficcional, torna-se uma espécie de 
narrativa em si, um corpo a ser lido, quando localizado no espaço e no tempo. Simultaneamente, ele é reflexo e também resposta às questões que assombram e instigam as mentes e os contextos que os produzem.

Consideremos duas narrativas vampirescas do século $\mathrm{XXI}$ nas quais o vampiro não apenas responde à tais anseios, como é também, ou carrega, um vetor epidemiológico. Se, em Drácula, o vampiro jamais chegou a multiplicar-se de maneira vertiginosa (a transmissão foi contida com sucesso pela formação de uma aliança entre os personagens masculinos, antes que se tornasse descontrolada), situações bem distintas ocorrem no romance Noturno (2009) de Guillermo del Toro e Chuck Hogan (primeiro volume da série conhecida como "Trilogia da Escuridão") e na série da Netflix Apocalipse $V$ (2019), que são distopias de teor apocalíptico nas quais a curva epidemiológica tornou-se rapidamente exponencial e descontrolada, causando a instauração de um cenário sombrio e devastador para a humanidade.

Em Noturno, é através da iconografia do avião que se instaura o clima de hesitação na narrativa. A chegada do voo 753, proveniente de Berlim, no aeroporto internacional JFK em Nova York deixa em alerta, inicialmente, a torre de controle do aeroporto, a Autoridade Portuária e, tão logo notificados, o CDC, centro de controle e prevenção de doenças norte-americano. O avião chegara em perfeito estado à pista, porém, desde sua aterrisagem, tornou-se completamente incomunicável. Na cabine, não havia qualquer sinal de som ou movimento. Se iniciam as especulações sobre o que pode ter acontecido: “'E se eles não puderem se mexer?' - murmurou, antes de se impedir de falar. 
'Uma situação com reféns? É isso que quer dizer?'” (DEL TORO; HOGAN, 2009, p. 19, tradução livre).

Uma das primeiras possibilidades levantadas pelas autoridades locais é a de uma ameaça terrorista. Desde que os aviões da United e American Airlines foram sequestrados e feitos de armas de destruição em massa contra os Estados Unidos no fatídico 11 de setembro de 2001, o país investiu de maneira significativa em "atividades de preparação para eventos de terrorismo [e] focaram principalmente em seus aspectos médicos e tecnológicos" (BOSCARINO; FIGLEY; ADAMS, 2003, p. 199, tradução livre), passando o combate ao terrorismo a ocupar um lugar de prioridade governamental - o que desencadearia, também, a Guerra ao Terror posta em ação por George W. Bush.

A apreensão em relação à tal possibilidade é palpável e logo ganha força. "'Se for uma bomba, eles esperaram até o último momento possível. [...] Estratégia clássica', disse, focado no terrorismo. 'Crie uma perturbação, atraia os socorristas, ganhe público - então detone, para o máximo impacto'” (DEL TORO; HOGAN, 2009, p. 20-21, tradução livre). Entretanto, quando a Autoridade Portuária de Nova York e Nova Jersey finalmente tem acesso ao avião, surge o entendimento de que ali se encontravam, possivelmente, diante de outro tipo de ameaça terrorista: aquela realizada através de armas biológicas. Os primeiros socorristas informam que os passageiros, incluindo os tripulantes, já se encontravam mortos, sem causa aparente - sem traumas, sangramentos, ou mesmo sinais de pânico ou luta. O avião, similarmente, estava completamente apagado, como em uma pane elétrica catastrófica. 
Entra em cena o Dr. Ephraim Goodweather, protagonista de Noturno, que é contactado pelo próprio diretor do CDC, em sua condição de líder do "Projeto Canário", cujo propósito era detectar e identificar rapidamente ameaças biológicas, fossem elas naturais ou produzidas artificialmente.

Um vírus requer transmissão, e transmissão leva tempo. Passageiros se sentindo mal ou desmaiando teriam causado uma bagunça, não importa o que dissesse o aviso de manter o cinto de segurança afivelado. Se isso era um vírus, era diferente de qualquer outro patógeno que Eph havia encontrado em seus anos como epidemiologista no CDC. Todos os sinais apontavam para algum tipo de agente letal introduzido no ambiente selado da cabine do avião. (DEL TORO; HOGAN, 2009, p. 47, tradução livre)

O fato de que o protagonista é um epidemiologista e de acompanharmos sua investigação científica, que se apropria de um vernáculo específico da área, somado também à ansiedade causada pelo temor do bioterrorismo, que se espalha pelas páginas ainda mais rápido que os agentes biológicos, aproxima Noturno do gênero conhecido como thriller biológico, que "organizado através do artifício do vírus, registra uma mudança prevalente na conceptualização da ameaça, uma mudança que associo ao advento da era global" (MAYER, 2007, p. 2, tradução livre).

Essa "era global" é de certa maneira materializada no próprio espaço onde o avião se encontra. Iniciar a ação com a imagem evocativa de um avião "morto", no aeroporto internacional de uma das metrópoles cosmopolitas das mais influentes do mundo globalizado, que fora previamente alvo de um ataque aéreo 
que deixou mais de 2,900 mortos, é uma escolha que registra e resgata marcas.

Na ocasião do 11/09, "feriu-se a integridade dos símbolos do poderio econômico dos Estados Unidos, e por consequência, a própria estrutura dos sentimentos de nacionalidade e patriotismo, tão prezados pelo povo norte-americano" (MAZZUOLI apud SILVA, 2013, p. 22). Os traumas deixados por tal evento, entretanto, têm consequências ainda mais pronunciadas entre os residentes de Nova York, como demonstra estudo (BOSCARINO; FIGLEY; ADAMS, 2003) realizado na cidade sobre o sentimento em relação ao Terror pós 11/09, que indica uma preocupação constante e elevada em relação aos temas do terrorismo e bioterrorismo.

Uma espécie de monstro nasceu naquele momento: o terrorista, que ganhou contornos quase sobrenaturais em sua aparente invisibilidade e, por consequência, onipresença. De certa forma, é possível pensar no próprio terrorismo como análogo a um vírus, no sentido de que "vive como parte do ambiente; às vezes latente, outras, virulento, mas sempre está lá, presente de alguma forma. Como um vírus, o terrorismo internacional não respeita fronteiras" (HAAS apud MAYER, 2007, p. 5, tradução livre).

A presença desse "monstro" é algo com o qual o povo norteamericano vem lidando há anos, e que foi sendo consolidada através de discursos como os do então presidente.

Nós sabemos que eles querem atacar novamente. Nossa nação tomou uma clara decisão: vamos confrontar esse perigo mortal à humanidade. $\mathrm{E}$ não vamos nos cansar, e não vamos descansar, 
até que vençamos a Guerra ao Terror. [...] Nos quatro anos desde o 11 de setembro, o mal que alcançou nossas margens ressurgiu. (BUSH, 2005, $s / p$, tradução livre)

Um discurso como esse poderia ter sido retirado, com mínimas adaptações, diretamente de uma narrativa vampiresca como Drácula, onde tínhamos um pequeno grupo de homens desempenhando o papel de "anticorpos" do corpo social, declarando guerra ao monstro-vampiro, em sua condição de defensores da moral doméstica. Em Noturno, que é uma narrativa já inserida no contexto da proteção e Guerra ao Terror, são as autoridades policiais portuárias e sanitárias que o fazem, em uma tentativa precoce de neutralizar qualquer corpo estranho que conseguiu, de alguma forma, penetrar no ambiente doméstico - justamente nesse espaço tão fronteiriço que representa um aeroporto do porte do JFK.

Como observamos no próprio contexto da pandemia de COVID-19, uma das primeiras medidas tomadas por muitos países foi, justamente, o fechamento de suas fronteiras, encerrando-se em si; o estrangeiro torna-se, mais uma vez, estranho, perigoso. Falar sobre contágios, vírus e pandemias é, hoje, sinônimo de falar sobre migrações, em um mundo tão intrinsecamente conectado.

É relevante observar também, como ilustração, o próprio fato de que ainda que cientistas tenham afirmado que o coronavírus não foi criado como uma arma biológica - hipótese que chegou a ser levantada em diversos meios (RINCON, 2020; CAIXETA, 2020) a COVID-19 foi retratada em determinados contextos, como aponta Ventura em "Pandemia e estigma: nota sobre as expressões 'vírus 
chinês' e 'vírus de Wuhan'” (2020), através de narrativas racistas, que atribuíam a responsabilidade e vilania da doença ao seu local de origem - e aos que lá residem, por consequência.

Quando os corpos dos passageiros finalmente são liberados para autópsia, alarmantes anormalidades são encontradas: uma substância branca viscosa neles se faz presente, tomando o lugar do que deveria ser o sangue; órgãos vitais como o coração e a própria estrutura arterial do corpo haviam sofrido alterações; novas estruturas haviam se formado.

Nora disse, "Impossível. Se passaram apenas trinta e seis horas desde a aterrisagem." Eph abriu o pescoço de Redfern, expondo sua garganta. Havia uma nova estrutura enraizada na altura do meio do pescoço, que crescia a partir das falsas cordas vocais. A protuberância parecia atuar como um tentáculo, em seu estado retraído. Era conectado diretamente à traqueia, fundindo-se, como um câncer. (DEL TORO; HOGAN, 2009, p. 189, tradução livre)

Mais tarde, eles descobririam que era através dessa estrutura, "uma readaptação da faringe, da traqueia e dos sacos pulmonares. Algo como a manga de uma jaqueta sendo invertida" (DEL TORO; HOGAN, 2009, p. 230, tradução livre), que o vampiro se alimenta, expelindo-a da cavidade oral.

Quando a substância branca presente nos corpos infectados é isolada para análise, é também detectada a presença de um helminto desconhecido, visível a olho nu, que poderia ser a explicação para as bizarras alterações pós-óbito. Tratava-se de um tipo de capillaria, tanto parasita quanto vetor, que introduzia um vírus incurável e de ação e acelerada, que manipulava os genes 
de seu hospedeiro e causava mutações radicais. Uma vez que o verme seja introduzido, através de qualquer laceração ou mesmo cavidade, o corpo seria para sempre hospedeiro desse altamente contagioso parasita, que se multiplica rapidamente.

As consequências de tais mudanças denominadas "impossíveis" seriam notadas quando os passageiros do voo 753, de alguma forma, começam a regressar aos seus lares.

Ansel ficou parado, sua garganta latejando, e então abriu o armário do cachorro, pegando a caixa de petiscos. [...] "Vem, amor" disse, num sussurro que rasgava sua alma. [...] Ansel pôs a mão no topo de sua cabeça, como ela gostava. Lágrimas escorriam de seus olhos enquanto fazia isso [...] e assim, pegou-a pela coleira e caiu sobre ela com todo seu peso. [...] A cadela uivou enquanto ele provava seu pelo, a textura de sua pele macia desaparecendo rapidamente após o jorro cálido do sangue [...] Ele estava bebendo a cadela. Bebendo, sem engolir. Ingerindo. Como se houvesse um novo mecanismo do qual não tinha ciência em sua garganta. Ele não podia entendê-lo; apenas entendia a satisfação que sentia. Um prazer paliativo no ato. E poder. Sim - poder. (DEL TORO; HOGAN, 2009, p. 167, tradução livre)

A cena retrata a primeira noite em que os passageiros retornam aos seus lares por instinto, doloridos e confusos, e com uma sede inexplicável por sangue. Nesse processo inicial, parte de suas identidades ainda se faziam notar, mas eram totalmente obliteradas pelo desejo de se alimentar; se Ansel experimentava conflitos ao alimentar-se de sua cadela Gertie, a proximidade perturbadora de seus entes queridos o faria acorrentar-se no canil em seu quintal. 
A maioria dos outros passageiros não seria tão forte, e logo os ataques vampirescos aconteceriam indiscriminadamente.

Os caminhos do doutor Ephraim Goodweather eventualmente se cruzam com os de Abraham Setrakian, que vinha acompanhando o desenrolar dos acontecimentos com atenção. Setrakian, exprofessor de literatura e folclore do Leste Europeu na Universidade de Viena, demonstrava vasto conhecimento sobre os últimos eventos, que ainda não haviam sido divulgados ao grande público inclusive, sobre o patógeno e a hematofagia.

"O que estamos testemunhando agora, em seu estágio inicial, já existe há séculos. [...] Uma estirpe de doença que corrompe tanto a carne quanto a alma. [...] Um vírus? Sim. Mas talvez eu devesse introduzi-lo a uma outra palavra que começa com v."

"Qual?", perguntou.

"Vampiro". Uma palavra dessas, dita com tamanha sinceridade, permanece pairando no ar por um tempo. [...]

"Eles sempre estiveram aqui", continuou. "Em seus ninhos, se alimentando. Em segredo e na escuridão, pois é de sua natureza." (DEL TORO; HOGAN, 2009, p. 215-216, tradução livre)

O fato de que um ataque pudesse estar acontecendo de forma tão pública fazia Setrakian acreditar, embora não soubesse afirmar o porquê, que algum tipo de jogo de poder ou plano com agenda insidiosa entrara em cena, pois esse era, "essencialmente, um ato de guerra" (DEL TORO; HOGAN, 2009, p. 216, tradução livre). Para ter sido tão bem-sucedido, o professor acreditava, inclusive, que o mesmo deveria ter tido a colaboração de algum 
humano de grande influência, pois até mesmo um vampiro dos mais antigos não poderia atravessar o oceano sem auxílio.

A aliança improvável entre strigoi - vocábulo oriundo da mitologia romena, que Setrakian usa para se referir aos vampiros - e um humano pode ser melhor entendida dentro de uma estrutura de desejo e poder; afinal, "nós desconfiamos e odiamos - monstro mas, ao mesmo tempo, invejamos sua liberdade" (COHEN, 1996, p. 17, tradução livre). Há certos aspectos inegáveis da vivência monstruosa que, de forma íntima, apelam aos desejos do humano; a própria origem do vocábulo "monstro" remonta a esta potencialidade - "monstrum é etimologicamente 'aquilo que revela' [do latim monstrare], 'aquilo que adverte' [do latim monere]" (COHEN, 1996, p. 4, tradução livre).

O mais rico ou influente dos humanos está confinado na carne e nos limites físicos e temporais por ela impostos, o que torna a ideia - e, no universo ficcional das narrativas vampirescas, a possibilidade - de um prolongamento indefinido da vida, acompanhado por força e habilidades sobre-humanas, algo extremamente fascinante para nós. A imortalidade é, afinal, a ruptura definitiva com a maior de nossas limitações, com aquilo que nos subjuga a todos igualmente.

Conhecemos assim a figura de Eldritch Palmer, homem de 76 anos identificado como o segundo mais rico do país, refém de doença crônica, gastando exorbitantes quantias de dinheiro para manter-se vivo e no poder que conquistou ao longo de sua vida; e a do "Mestre", um dos vampiros originais, que rebelou-se de seu clã e de sua existência nas sombras, tendo novos planos para a 
humanidade. Eles entram em um acordo: Palmer faria uso de sua influência e fortuna para facilitar a entrada do Mestre (no porão de um voo comercial, no qual infectaria todos os passageiros) nos Estados Unidos, construindo também usinas nucleares em pontos estratégicos espalhados pelo mundo, que seriam detonadas em momento oportuno para a criação de um grande "inverno nuclear", onde os strigoi poderiam caminhar livremente, sem temer o sol. Como recompensa, Palmer obteria um lugar de destaque ao lado do Mestre, na forma de imortal, em meio à nova ordem mundial que seria instaurada - com os humanos relegados ao status de alimento, presos em fazendas apenas para procriação e abate, como gado.

A abjeção, ainda que prevalente na descrição do encontro com o Mestre, é sobrepujada pelo senso e expectativa de inesgotável poder. "O horror. E a glória. O ímpio. E o magnífico. O selvagem. E o sagrado. [...] O grotesco transcendente. Olhai o Mestre" (DEL TORO; HOGAN, 2009, p. 310, tradução livre). No Mestre, Palmer pôde vislumbrar uma parte obscura e desenfreada de si mesmo, uma exponenciação de seus desejos por soberania; é uma projeção que funciona através do corpo monstruoso, lugar onde "as fantasias de agressão, dominação e inversão são permitidas expressão livre" (COHEN 17).

Ademais, é possível observar a forma como o corpo do vampiro também ganha, ao lado das usinas nucleares, um status de arma de guerra, de destruição em massa; funciona como uma engenhosa arma biológica que converte o "inimigo" em "aliado", fundamental na criação de um verdadeiro exército de corpos infectados. 
Enquanto isso, a preocupação do professor Setrakian se exponencia na mesma medida da taxa de transmissão do vírus, afinal, o avião representara apenas a forma de introdução do vírus vampiresco no "corpo" social; era como seu conduíte, o vetor. Seguindo essa analogia, os passageiros em si seriam o próprio vírus - algo que Ephraim leva ao nível do discurso, quando diz que "o vírus dominava e transforma as células - assim como o vampiro dominava e transformava a vítima. Estes vampiros eram vírus encarnados" (DEL TORO; HOGAN, 2009, p. 277, tradução livre, grifo nosso) - e estes já haviam se espalhado. Dessa forma, cada noite representaria uma nova onda de transmissão viral, e "a segunda onda de infecção está acontecendo agora" (DEL TORO; HOGAN, 2009, p. 245, tradução livre).

A narrativa se aproxima do clímax no lugar onde os protagonistas conseguiram rastrear o Mestre: a própria área de fundação subterrânea das Torres Gêmeas, alvos dos ataques terroristas de 11 de setembro. Por um lado, o professor explica que há uma razão mais prática pela qual o Mestre ali buscou refúgio: "o lugar o atraiu', disse Setrakian. 'Uma toupeira faz uma casa no tronco morto de uma árvore caída. A gangrena se forma numa ferida. Ele é enraizado em tragédia e dor" (DEL TORO; HOGAN, 2009, p. 367, tradução livre).

Por outro, é possível traçar um paralelo entre o fato de que a narrativa se inicia com a iconografia do avião - que funcionou como arma de destruição em massa no ataque terrorista de 11/9 e que, na narrativa, foi o "vetor" do vírus vampiresco - e de que se aproxima do fim no próprio local que carrega as marcas físicas da destruição por aviões causada; o mesmo local para onde as 
câmeras e os olhos do mundo inteiro estavam virados naquele dia, testemunhando a queda das Torres Gêmeas do World Trade Center. Tal local, assombrado pela imagem das Torres destruídas, e agora habitado pelo Mestre, funcionaria como um prenúncio do poder destrutivo de uma pandemia vampiresca, capaz de fazer ruir as mais fortes fundações. O fim da narrativa marcava o início do apocalipse hematófago de Noturno, que continuaria com os romances A Queda (2010) e Noite Eterna (2011).

Já em Apocalipse $V$, uma diferença fundamental se estabelece em relação à Noturno, que é o próprio fato de que a contaminação não se dá inicialmente de maneira orquestrada, em cumprimento a uma agenda insidiosa; aqui, o que temos é um cenário que se desenvolve a partir de uma descoberta acidental.

Somos apresentados ao Dr. Luther Swann, cientista especializado em doenças infecciosas, no que ele faz um profético alerta a comunidade científica em uma conferência: "Se querem saber, não acho que serão os asteroides ou uma guerra nuclear que nos exterminará. Vai ser isso" (APOCALIPSE V, 2019, ep. 1), comenta, apontando em um slide a foto ampliada de um vírus.

Sabemos que a mudança climática está provocando a deterioração glacial. Também sabemos que há vírus e bactérias presos no gelo que está derretendo. Agora, imaginemos que o equivalente pré-histórico da zika, do ebola ou da peste bubônica aparecesse por causa do degelo. Nossos corpos não teriam imunidade. Não teríamos vacinas que pudessem nos ajudar. (APOCALIPSE V, 2019, ep. 1)

Tal associação é oriunda do fato de que Swann assessora uma pequena equipe que realiza pesquisas no Ártico. Quando ele é 
convocado para averiguar uma descoberta recente na estação da equipe na região, o cenário que encontra é desolador: a estação abandonada, com marcas de sangue, mas sem sinais de corpos; encontra apenas, em um frasco rompido no chão e marcado com o símbolo universal de risco biológico, algum tipo de biomassa desconhecida. Swann, acompanhado de Michael, que o transportou de helicóptero até o local, pesarosamente informa ao acompanhante que, o que quer que esteja ali contido, eles sofreram exposição e precisam reportar o incidente.

Desde o início percebemos como, mais uma vez, a trama se aproxima do thriller biológico, tanto na figura do protagonista e em sua apropriação do discurso viral, como no desejo de "estabelecer uma ponte entre a fantasia e a realidade, entre a ficção especulativa e o conhecimento científico" (MAYER, 2007, p. 2, tradução livre). A narrativa se ancora em uma ansiedade advinda de nossa fragilidade, apesar dos desenvolvimentos científicos, de defrontar um vírus ou patógeno novo, com o qual poderíamos não ter tempo suficiente para lidar de forma eficiente - algo que viria a materializar-se no mundo real poucas semanas após o lançamento da série (no dia 5 de dezembro de 2019, mais precisamente), no contexto da COVID-19 que, ao longo do ano de 2020, seria responsável pelo óbito de mais de um milhão e meio de pessoas ao redor do mundo, no aguardo de uma vacina.

A narrativa segue com o protocolo padrão pós-exposição a um agente infeccioso potencialmente perigoso: a quarentena, que, no caso de Swann e Michael, ocorre nos escritórios do CDC em Washington, onde os personagens são mantidos em isolamento. Tosse, enjoos e febre compõem os sintomas apresentados por 
Swann; Michael parece permanecer assintomático. O período chega ao fim - prematuramente, na própria opinião de Swann - quando eles se encontram aparentemente recuperados e com os resultados de exames obtidos, inconclusivos, o que os leva a conjecturar que podem ter sido vítimas de algum tipo inofensivo de resfriado da Era Glacial.

Com efeito, o fim do isolamento se mostraria prematuro, uma vez que Swann e Michael haviam sido testados para os tipos de agentes infecciosos conhecidos; na verdade, eles haviam sido infectados por uma variedade muito antiga de príons - patógenos que não possuem DNA ou RNA, ao contrário de vírus e bactérias isolados e preservados em biomassa. Príons são responsáveis por alguns tipos de encefalopatias humanas, porém, mais popularmente, pela encefalopatia espongiforme bovina - vulgarmente, a "doença da vaca louca".

Sabemos que, se a contenção funcionasse, não teríamos como resultado essa ou outras narrativas apocalípticas pandêmicas; porém, o próprio fato de que "cenários atuais de ameaça, de forma crescente, giram em torno da suspeita de que a contenção não funciona mais, ou melhor, que as medidas de contenção precisam ser atualizadas e refinadas" (MAYER, 2007, p. 4, tradução livre), aponta para essa constante preocupação da contenção, que ecoa também uma misofobia que se exponencia em sociedades que vivem momentos de isolamento e quarentenas.

No contexto narrativo, esse tipo específico de príon depende ainda de um cofator decisivo para que seja desenvolvida a condição do vampirismo: um gene denominado $\mathrm{NH}-47$, que comporia o 
"DNA-lixo" - porções da sequência de DNA sem função discernível identificada - de somente algumas pessoas. Swann não tinha o "gene predador", foi infectado, apresentou sintomas, e curou-se; Michael, por outro lado, foi infectado e permaneceu assintomático, porém, tinha o gene $\mathrm{NH}-47$.

Considerando particularmente a questão de uma predisposição genética - similar ao que ocorre com pessoas que apresentam genes que aumentam consideravelmente a probabilidade de desenvolver alguns tipos de câncer - como determinante para o vampirismo, podemos levantar alguns pontos que dela se desdobram.

Em primeiro lugar, a ciência poderia acabar contribuindo, ainda que indireta e involuntariamente, com a discriminação e perseguição de um grupo determinado de pessoas que, em contato com os príons, poderiam vir a tornar-se vampiros, por meio do mapeamento genético. Uma população com medo e em pânico torna-se uma população perigosa e, quando a infecção começa a se espalhar - consequentemente levando, sem demora, a um número cada vez maior de ataques aos humanos - logo surgem grupos de justiceiros e vigilantes, expurgando seus próprios desejos íntimos pela caça e pela violência, até então reprimidos, aproveitando-se do fato de que as forças policiais falham em controlar a situação.

Entretanto, não necessariamente somente os vampiros eram alvo; o apenas ter sofrido exposição parecia ser, em alguns casos, motivação suficiente para estes grupos mais bárbaros que os próprios vampiros. A vizinha de uma casa onde um massacre havia ocorrido relata que os responsáveis "foram pessoas. [...] Não sei 
quem contou a eles [aos justiceiros] que o pessoal daquela casa era sanguessuga. A maioria não era" (APOCALIPSE V, 2019, ep. 7). Aqui, tanto a informação - em mãos erradas, a informação genética de uma pessoa poderia tornar-se uma arma contra ela - quanto a falta dela, demonstrada por um governo que tentou, sem sucesso, manter a população às escuras sobre o cenário que se desenhava, contribuíam para um caos generalizado.

É importante sublinhar também o próprio fato de que os vampiros são corpos infectados, que se tornaram hematófagos por uma questão de predisposição genética inteiramente natural e independente de sua escolha. Ademais, diferente dos vampiros de Noturno, que logo tornavam-se fantoches nas mãos do Mestre, meros soldados famintos e homicidas, aqui os vampiros detêm muito de sua personalidade humana, sendo capazes de fazer suas próprias escolhas. Como o vampiro é, aqui, mais sociável e reflexivo, cria-se uma discussão sobre a possível culpabilização e perseguição da vítima - ou seja, do vampiro - que não deixa de ser, simultaneamente, vítima e vetor. Michael, o "paciente zero", quando confrontado por Swann, diz que "Eu também tenho o direito de viver. [...] Eu sou uma nova espécie" (APOCALIPSE V, 2019, ep. 4).

Recuperando a ideia anteriormente mencionada do terrorismo "latente" de Haas, que o associa a um vírus - mesmo não estando em estágio de contaminação, se mantém presente, oculto -, aqui de maneira similar temos essa possível "espécie" distinta de humano, não extinta, apenas latente e que existia ao nosso lado. A questão posta é de até que ponto uma espécie teria direito prevalente sobre a outra; em síntese, ainda que uma tenha o direito de se defender, a outra teria o direito de se alimentar. 
Tendo em consideração o histórico de guerras por poder da humanidade, entretanto, não é difícil imaginar qual seria a reação generalizada de um povo que se vê às voltas com a possibilidade de não mais estarem no topo da cadeia alimentar.

Quando o governo finalmente decide fazer um pronunciamento oficial sobre a situação, já fora de controle, o discurso sobre a "doença infecciosa" que desencadeia comportamentos potencialmente assassinos é incisivo: "não se enganem. Isso é terrorismo. Uma forma completamente nova. [...] Descobrirão que não os tememos. Pelo contrário, vamos reagir com tudo à violência deles" (APOCALIPSE V, 2019, ep. 5), o que é bastante evocativo dos discursos do presidente norte-americano Bush diante da Guerra ao Terror: "vamos confrontar esse perigo mortal à humanidade. $\mathrm{E}$ não vamos nos cansar, e não vamos descansar, até que vençamos" (2005, s/p, tradução livre).

Nesse ponto da narrativa, a ligação que o governo estabelece entre o vampirismo e o terrorismo pode ser entendida como nada mais que uma justificativa pública para a resposta violenta que se seguiria, afinal, o advento da propagação da contaminação não se tratava de um plano orquestrado por alguém, como em Noturno; ainda assim, uma nova era de perseguição seria instaurada, com a formação de campos de concentração e de grupos de extermínio "legais" ou não. Era o início de um cenário de guerra.

Michael, através de uma transmissão clandestina pela internet, responde ao discurso de ódio ao endereçar, simultaneamente, humanos e vampiros. Ele diz,

Quando surgiram os humanos, foi o fim dos neandertais e dos denisovanos. Os humanos 
reinaram sozinhos nesse planeta por 42 mil anos. Foi bom enquanto durou, e durou bastante. [...] Aos companheiros escondidos nas sombras, é hora de sair para a luz. É hora de se orgulhar do que você é. (APOCALIPSE V, 2019, ep. 5)

Nesse sentido, Apocalipse $V$ recupera também uma vertente da arte contemporânea que usa a figura dos vampiros - tradicionalmente seres das margens, confinados às sombras, muitas vezes sem voz - como metáforas para minorias buscando visibilidade; algo explorado de maneira bastante fértil nas Crônicas Vampirescas de Anne Rice, a partir da década de 70, com seu primeiro romance Entrevista com o Vampiro (1976), e na série Crônicas de Sookie Stackhouse, de Charlainne Harris, adaptada para a televisão na série da HBO True Blood (2008-2014).

Quando Swann negocia com Michael os termos de uma possível trégua, o último pede para que os vampiros sejam reconhecidos legalmente como uma espécie humana distinta, mas Swann afirma que, no governo, um lado "diz para curar a todos; o outro para matar a todos. Ninguém está defendendo a diversidade" (APOCALIPSE V, 2019, ep. 9). Se, por um lado, o governo não contava com a possibilidade de que os vampiros não quisessem ser "curados" de sua condição - que, de fato, incluía benefícios atraentes aos quais já nos referimos em nossa discussão de Noturno, como a força, visão e audição exponencialmente aumentadas, sem falar na possível imortalidade - por outro, se pensarmos na leitura alegórica dos vampiros enquanto um grupo socialmente marginalizado, tal busca seria não apenas compreensível como também esperada. A discussão reflete, por exemplo, as terapias de reorientação 
sexual que inexplicavelmente ainda existem nos dias de hoje, também chamadas de "terapias de conversão" ou ainda, vulgarmente, a "cura gay".

Outro paralelo que se estabelece em relação à True Blood é o fato de que também é desenvolvida uma bebida sintética, aqui batizada de "SubSangue" (ou "BloodSub", no original), que em teoria permitiria que os vampiros vivessem normalmente ao lado da humanidade, alimentando-se apenas do composto. Mais além, alguns familiares de vampiros e até mesmo voluntários mostramse dispostos a doar seu sangue para estimular uma coexistência pacífica. Tais tentativas, entretanto, fracassam quando, em um evento público de demonstração do SubSangue, os vampiros que haviam demonstrado interesse na possibilidade de conciliação, confiando nos humanos, começam a cair mortos, envenenados pela substância. Aparentemente, o "lado" do governo que queria "matar a todos" não se contentou com uma coexistência pacífica ao lado de tais "monstros", que poderiam desestabilizar sua estrutura de poder; por isso, interviram no processo possivelmente apaziguador, em um ato violento de Terror.

A ideia de terrorismo de estado reverbera aqui, algo que Silva aponta quando fala de governos que

aproveitaram a disseminação do medo e da intimidação para alcançar, pelo uso da violência, objetivos que poderiam, ou deveriam, ser obtidos por meio do exercício legal da vontade política. De tal modo, o faziam através da prática de tortura, prisões, extermínios, deportações; invocando razões de Estado (ou de segurança); logo, negligenciaram os direitos das minorias étnicas, religiosas ou políticas. (2013, p. 49-50) 
$\mathrm{O}$ ato teria consequências desastrosas para todos, humanos e vampiros. Michael, por ter sido considerado culpado pelas negociações desastrosas com humanos, é "deposto" de seu lugar de liderança na autointitulada "Nação Sanguínea". Em seu lugar, um cientista que era ligado ao Departamento de Segurança Nacional, com vasto conhecimento sobre as estratégias governamentais para lidar com os vampiros, anuncia ao mundo por transmissão na internet que juntou-se ao grupo que iria prevalecer, tendo se exposto aos príons deliberadamente por ser portador do gene predador, e oferecendo todo o conhecimento que tinha aos vampiros em troca de uma posição de liderança. Ele alerta:

Só pode haver um vencedor nessa batalha pela sobrevivência, nessa luta evolutiva, e humanos, fracos, divididos e aterrorizados, simplesmente não merecem vencer. [...] Nunca mais, por qualquer razão, voltaremos a lidar com humanos. [...] Colocamos uma grande quantidade dessa substância [a fonte do príon infeccioso, em forma líquida] no abastecimento de água de várias grandes cidades, expondo 30 milhões de pessoas à infecção por príon. [...] Os vampiros estão aqui para ficar. E para vencer. (APOCALIPSE V, 2019, ep. 10)

Por mais distintos que tenham sido os caminhos percorridos inicialmente pelas narrativas de Noturno e Apocalipse $V$, elas convergem no clímax em um ponto fundamental, que é a utilização do corpo do vampiro como arma biológica, na formação de um exército em uma iminente guerra por poder. Se no caso da última a contaminação não aconteceu, no princípio, de forma deliberada, após a instauração de uma "Guerra ao Vampiro" ela acontece como declaração de guerra. 
Além da inquietação oriunda do "monstro" construído como terrorista estrangeiro, das armas biológicas e de pandemias catastróficas, percebe-se também nessas narrativas um comentário sobre como a própria luta pelo poder pode ser ainda mais devastadora que esses próprios anseios. Em Noturno, o Mestre se escorou na vontade de força e poder de um humano para concretizar seu plano sombrio; em Apocalipse $V$, o que poderia se desenhar como uma possível coexistência entre espécies fracassa diante de desejos irrefreados por soberania. O monstro-vampiro apenas reflete essas monstruosidades tão nossas, ele que "incorpora medos, desejos, ansiedades e fantasias (ataráticas ou incendiárias), que os dão vida" (COHEN, 1996, p. 4, tradução livre).

Se Noturno estava endereçando angústias mais particulares de um local e um momento pós-11/9, e a pandemia iniciada em Apocalipse $V$ seja um produto da imaginação que é anterior ao contexto da COVID-19, nosso olhar para narrativas como estas ganha, sem dúvidas, novas camadas de significação no que atravessamos uma pandemia real. Quando o Dr. Swann alerta, "não acho que serão os asteroides ou uma guerra nuclear que nos exterminará. Vai ser isso [um vírus]" (APOCALIPSE V, 2019, ep. 1), é impossível não pensar nas tragédias que se abateram sobre tantas famílias ao redor do globo; tragédias essas que foram anunciadas inúmeras vezes pelo mundo especulativo da ficção, cujos horrores são sempre tão enraizados no real - e, por isso, podem tornar-se possíveis, servindo como alerta. Nesse sentido é, no mínimo, perturbador observar como a pandemia real tornase também uma batalha por poder político, que inclui discussões, 
por exemplo, sobre a não-utilização de uma vacina chinesa no Brasil (PARAGUASU, 2020), oriunda da culpabilização xenofóbica ao qual nos referimos anteriormente.

Por fim, além de observar reverberações dessas narrativas vampirescas pandêmicas na atualidade, torna-se factível também presumir que algumas das próximas encarnações do vampiro na literatura irão se apropriar, de maneira ainda mais íntima e peculiar, das ansiedades que se desdobram a partir do surgimento do novo coronavírus; afinal, nossos monstros-vampiros nada mais são que produtos engendrados pela cultura e pela sociedade, como formas atraentes, inquietantes e catárticas de lidar com as angústias e os medos que os afligem.

\section{REFERÊNCIAS}

APOCALIPSE V. Direção de Brad Turner e outros. Netflix, 2019. Disponível em: https://www.netflix.com/watch/80236118?source=35. Acesso em 1 out. 2020. BíBLIA. Português. A Bíblia Sagrada: Velho Testamento e Novo Testamento. Rio de Janeiro: Imprensa Bíblica Brasileira, 1990.

BOSCARINO, Joseph A.; FIGLEY, Charles R.; ADAMS, Richard E. Fear of Terrorism in New York After the September 11 Terrorist Attacks: Implications for Emergency Mental Health and Preparedness. International Journal of Emergency Mental Health, vol. 5, p. 199-209, 2003. Available at: https://pubmed.ncbi.nlm.nih. gov/14730761/. Access on 8 nov. 2020.

BUSH, George W. President Discusses War on Terror. George W. Bush White House Archives, 28 out. 2005. Available at: https://georgewbush-whitehouse. archives.gov/news/releases/2005/10/20051028-1.html. Access on 27 oct. 2020. CAIXETA. Bolsonaro cita arma biológica e diz que coronavírus "talvez tenha escapado". Metrópoles, 29 out. 2020. Disponível em: https://www.metropoles. com/brasil/politica-brasil/bolsonaro-cita-arma-biologica-e-diz-que-coronavirustalvez-tenha-escapado. Acesso em 1 nov. 2020. 
COHEN, Jefrrey Jerome. Monster Culture (Seven Theses). In: COHEN, Jefrrey Jerome. Monster Theory: Reading Culture. Minneapolis: University of Minnesota Press, p. 3-25, 1996.

DEL TORO, Guillermo; HOGAN, Chuck. The Strain. New York: HarperCollins Publishers, 2009.

JONES, Lora; PALUMBO, Daniele; BROWN, David. Coronavirus: A visual guide to the economic impact. BBC News, 29 jun. 2020. Available at: https://www.bbc. com/news/business-51706225. Access on 1 nov. 2020.

MAYER, Ruth. Virus Discourse: The Rhetoric of Threat and Terrorism in the Biothriller. Cultural Critique, n. 66, p. 1-20, 2007. Available at: www.jstor.org/ stable/4539806. Access on 8 nov. 2020.

PARAGUASSU, Lisandra. Bolsonaro comemora suspensão de testes da CoronaVac pela Anvisa. Extra, 10 nov. 2020. Disponível em: https://extra. globo.com/noticias/mundo/bolsonaro-comemora-suspensao-de-testes-dacoronavac-pela-anvisa-rv1-1-24738102.html. Acesso em 21 nov. 2020.

RINCON, Paul. Coronavírus: há alguma evidência de que o sars-cov-2 tenha sido criado em laboratório? BBC News Brasil, 1 maio 2020. Disponível em: https:// www.bbc.com/portuguese/geral-52506223. Acesso em 1 ago. 2020.

SILVA, Evelyn Veríssimo da. A Guerra ao Terror: um atentado a consolidação dos direitos humanos pós 11/09. Orientador: Ernani Carvalho. Dissertação (Mestrado em Ciência Política) - Universidade Federal de Pernambuco, Pernambuco, 2013. Disponível em: https://repositorio.ufpe.br/ handle/123456789/12473. Acesso em 2 nov. 2020.

STOKER, Bram. Drácula. São Paulo: Landmark, 2014.

TOMC, Sandra. Dieting and Damnation: Anne Rice's Interview with the Vampire. In: GORDON, Joan; HOLLINGER, Veronica. Blood Read: The Vampire as Metaphor in Contemporary Culture. Philadelphia: University of Philadelphia Press, p. 95-113, 1997. VENTURA, Deisy. Pandemia e estigma: nota sobre as expressões "vírus chinês" e "vírus de Wuhan". Museu da Imigração do Estado de São Paulo, 11 set. 2020. Disponível em: https://museudaimigracao.org.br/blog/migracoes-em-debate/ pandemia-e-estigma-nota-sobre-as-expressoes-virus-chines-e-virus-de-wuhan. Acesso em 2 nov. 2020. 